\title{
Prevalence of infections and co-infections with 6 pathogens in Dermacentor reticulatus ticks collected in eastern Poland
}

\author{
Violetta Zając', Angelina Wójcik-Fatla', Anna Sawczyn', Ewa Cisak1, Jacek Sroka², Anna Kloc', \\ Zbigniew Zając ${ }^{3}$, Alicja Buczek³ ${ }^{3}$ Jacek Dutkiewicz', Katarzyna Bartosik ${ }^{3}$ \\ ${ }^{1}$ Department of Health Biohazards and Parasitology, Institute of Rural Health, Lublin, Poland \\ ${ }^{2}$ Department of Parasitology and Invasive Diseases, National Veterinary Research Institute, Pulawy, Poland \\ ${ }^{3}$ Chair and Department of Biology and Parasitology, Medical University, Lublin, Poland
}

\begin{abstract}
Zając V, Wójcik-Fatla A, Sawczyn A, Cisak E, Sroka J, Kloc A, Zając Z, Buczek A, Dutkiewicz J, Bartosik K. Prevalence of infections and co-infections with 6 pathogens in Dermacentor reticulatus ticks collected in eastern Poland. Ann Agric Environ Med. $2017 ; 24(1)$ : 26-32. doi: $10.5604 / 12321966.1233893$
\end{abstract}

\begin{abstract}
Occurrence of co-infections with various pathogens in ixodid ticks creates a risk of increased severity of tick-borne diseases in humans and animals exposed to bite of the ticks carrying multiple pathogens. Accordingly, co-infections in ticks were subject of numerous analyses, but almost exclusively with regard to Ixodes ricinus complex whereas potential tick vectors belonging to other genera were much less studied. Taking into consideration the role of Dermacentor reticulatus in the transmission of various pathogens, we carried out for the first time the comprehensive statistical analysis of co-infections occurring in this tick species. An attempt was made to determine the significance of the associations between 6 different pathogens occurring in D. reticulatus (Tick-borne encephalitis virus = TBEV, Anaplasma phagocytophilum, Rickettsia raoultii, Borrelia burgdorferi s. I., Babesia spp., Toxoplasma gondii), using 2 statistical methods: determination of Odds Ratios (ORs) and the Fisher's exact test. 634 questing Dermacentor reticulatus ticks (370 females and 264 males) were collected in 20112013 by flagging the lower vegetation in 3 localities in the area of Łęczyńsko-Włodawskie Lakeland, situated in the Lublin region of eastern Poland. The presence of individual pathogens was detected by PCR. Ticks were infected most often with Rickettsia raoultii (43.8\%), less with TBEV (8.5\%), and much less with Babesia spp., Toxoplasma gondii, Borrelia burgdorferi s.I., and Anaplasma phagocytophilum (2.5\%, $2.1 \%, 1.6 \%$ and $1.1 \%$, respectively). The locality-dependent variability proved to be significant for TBEV $\left(\chi^{2}=11.063 ; \mathrm{P}=0.004\right)$ and Toxoplasma gondii $\left(\chi^{2}=11.298 ; \mathrm{P}=0.0035\right)$, but not for other pathogens. Two hundred seventy (42.6\%) of the examined ticks were infected only with a single pathogen, and 54 (8.5\%) showed the presence of dual co-infections, each with 2 pathogens. The most common were dual infections with participation of Rickettsia raoultii (7.41\%); next, those with participation of the TBEV (5.21\%), Toxoplasma gondii (1.58\%), Borrelia burgdorferi s.I. (1.26\%), Anaplasma phagocytophilum (0.95\%), and Babesia spp. (0.63\%). On the total number of 15 possible associations, in 9 cases co-infections occurred whereas in 6 cases they were not detected. The most noteworthy were positive co-infections with the participation of TBEV, which proved to be weakly significant $(0.05<\mathrm{P}<0.1)$ in associations with Toxoplasma gondii and Anaplasma phagocytophilum, with Odds Ratios over 3.3 and 4.4, respectively. The values of Odds Ratios exceeded 3.0 also at the co-infections of Rickettsia raoultii with B. burgdorferi s.I., and T. gondii with Babesia spp., but these associations did not attain a significance level. The co-infections of Rickettsia raoultii with Babesia spp. appeared not to be significant $(0.05<\mathrm{P}<0.1)$ with OR below 0.3 . In conclusion, co-infections with various pathogens in $D$. reticulatus ticks seem to be relatively rare and mostly not significant.
\end{abstract}

\section{Key words}

Dermacentor reticulatus, co-infections, TBE virus, Anaplasma phagocytophilum, Rickettsia raoultii, Borrelia burgdorferi sensu lato, Babesia spp., Toxoplasma gondii

\section{INTRODUCTION}

Hard ticks (Ixodidae) transmit a range of viruses, bacteria and protozoa pathogenic for humans and animals. The occurrence of co-infections (multiple infections with pathogens of different genera) or mixed infections (multiple infections with pathogens of the same genus), could be of medical significance because of increased severity of pathologic symptoms [1]. The prevalence of co-infections has been studied mostly within Ixodes ricinus complex [2, $3,4,5]$, whereas potential tick vectors belonging to the other genera were much less studied.

Address for correspondence: Angelina Wójcik-Fatla, Institute of Rural Health, Jaczewskiego 2, 20-090 Lublin, Poland

E-mail:afatla@poczta.onet.pl

Received: 10 January 2017; accepted: 14 February 2017; first published on March 2017
Dermacentor reticulatus (Fabricius, 1794) is an Eurasian tick species, known as marsh tick or ornate dog tick. This species is regarded as the second most important vector of tick-borne pathogens in Europe, next to I. ricinus [6, 7, 8]. D. reticulatus has been classified by Estrada-Peňa and Jongejan [9] as a pathogen-transmitting tick commonly reported on humans and ungulates.

The area of occurrence of $D$. reticulatus extends from Portugal in the West to Western Siberia in the East and comprises the Western-European and the Eastern tick populations. Both populations are separated by a gap not inhabited by $D$. reticulatus, which is shrinking because of rapid expansion of marsh ticks to new areas. The spatial expansion of $D$. reticulatus in Poland is associated with the increase of the number of ticks which, in some areas of central and eastern Poland, became dominant over I. ricinus [10, 
$11,12,13,14,15,16,17]$. These findings indicate a growing significance of marsh ticks as potential vectors of tick-borne diseases $[8,16]$.

The role of $D$. reticulatus in the circulation and transmission of tick-borne pathogens remains poorly known. Nevertheless, $D$. reticulatus has been demonstrated to harbour various tick-borne pathogens of humans and/or animals, such as tick-borne encephalitis virus (TBEV), Omsk haemorrhagic fever virus, Kemerovo virus, Anaplasma phagocytophilum, Anaplasma marginale, Spotted Fever Group Rickettsiae (SFGR), such as Rickettsia raoultii and Rickettsia slovaca, Borrelia burgdorferi sensu lato (s.l.), Francisella tularensis and Francisella-like endosymbionts, Coxiella burnetii, Bartonella spp., Babesia canis, Babesia caballi, Babesia microti, Babesia divergens, Babesia bigemina, and Theileria equi [7, 8, 18-32].

The best documented is the important role of $D$. reticulatus as a vector of the babesiosis in dogs caused by Babesia canis $[18,33,34]$. It is also regarded as a vector of Rickettsia raoultii and Rickettsia slovaca causing tick-borne lymphadenopathy (TIBOLA) in humans. Földvári et al. [26] has demonstrated recently a direct relationship between the bite of a man by $D$. reticulatus and development of TIBOLA caused by Rickettsia raoultii. The role of this tick species in the transmission of some other pathogens in domestic animals and humans was also confirmed for Babesia caballi, Theileria equi, Anaplasma marginale, and Omsk haemorrhagic fever virus [18]. The role of $D$. reticulatus as a vector of other pathogens is less known, but seems probable with relevance to TBEV, and less probable with relevance to Francisella tularensis, Coxiella burnetii and Babesia microti $[8,18,24$, $25,29-31,35]$.

In contrast to the Ixodes ricinus complex, the prevalence and significance of co-infections occurring in D. reticulatus has not been extensively studied. Taking into consideration the possible role of this tick species in the transmission of tick-borne pathogens, we carried out for the first time a comprehensive analysis of co-infections occurring in D. reticulatus. We attempted to determine the character of the associations between 6 different pathogens occurring in this tick species, utilizing 2 statistical methods used by Nieto and Foley [4] and by our group [36] for assessment of the significance of co-infections occurring in Ixodes ticks: determination of Odds Ratios (ORs) and the Fisher's exact test.

The presented study includes into the analysis of coinfections with 5 pathogens described earlier as indigenous for D. reticulatus (TBEV, Anaplasma phagocytophilum, Rickettsia spp., Borrelia burgdorferi s.l., Babesia spp.), adding as a sixth pathogen, an apicomplexan parasite Toxoplasma gondii which, until recently, has not been regarded as a tickborne pathogen. This protozoan occurs in wide range of vertebrate hosts, spreads by the oral route, and completes its life cycle in cat's intestine [37]. However, as T. gondii DNA has been detected already in Dermacentor reticulatus ticks from eastern Poland [38], from Ixodes ricinus ticks from various areas of Poland [39-41], and recently also from Haemaphysalis longicornis ticks in China [42], the tick-borne spread of this parasite cannot be excluded, and we have therefore included it into the current analysis as a novel element.

\section{MATERIALS AND METHOD}

Collection of ticks. A total of 634 adult questing D. reticulatus ticks (370 females and 264 males) were collected from spring to autumn in 2011-2013 in 3 localities situated in the Lublin province (eastern Poland): Ostrów Lubelski, Parczew and Włodawa. Ticks were collected by dragging a woolen flag over the lower vegetation and litter along the paths and edges of deciduous and mixed forests, and kept alive until further investigation.

DNA and RNA isolation. All ticks were examined individually and after collection each tick was cut in half. From one part of the tick, after homogenization, total DNA was isolated by boiling in $0.7 \mathrm{M}$ ammonium hydroxide [43] and stored at $-20 \mathrm{C}$ for further analysis. The second half of tick was crushed in liquid nitrogen, homogenized with a syringe needle and suspended in buffer containing guanidine isothiocyanate (GITC), inhibiting RNase enzyme. Total RNA was extracted using RNeasy Mini Kit (Qiagen, USA) according to the producer's instruction. The concentration of DNA and RNA in the isolates was determined with the NanoDrop ND1000 Spectrophotometer (USA). DNA concentration ranged from $240-460 \mathrm{ng} / \mu \mathrm{l}$ and RNA concentration ranged from $15-60 \mathrm{ng} / \mu \mathrm{l}$.

Detection of pathogens by PCR. Using polymerase chain reaction (PCR), DNA isolates were examined for the presence of A. phagocytophilum, Rickettsia spp., B. burgdorferi s.l., Babesia spp., and T. gondii, while RNA isolates were examined for the presence of TBEV. All amplifications were carried out in C1000 Thermal Cycler (BioRad, USA).

Detection of A. phagocytophilum was performed according to Massung et al. [44] using amplification by PCR and confirmatory re-amplification by nested-PCR. Each PCR reaction was carried out in a $25 \mu \mathrm{l}$ reaction volume which contained the following mix of reagents: $1.25 \mathrm{U}$ Taq DNA polymerase (Qiagen, USA), $1 \times \mathrm{PCR}$ buffer containing $15 \mathrm{mM} \mathrm{MgCl}, 2.5 \mu \mathrm{l} 2 \mathrm{mM}$ dNTP (final concentration $0.2 \mathrm{mM}$ ) (Thermo Scientific), $1.25 \mu \mathrm{l} 10 \mu \mathrm{M}$ each of primer for the first amplification (ge3a/ge10) or $0.5 \mu \mathrm{l} 10 \mu \mathrm{M}$ each of primer for nested-PCR (ge9/ge2), $2.5 \mu \mathrm{l}$ of isolated DNA and nuclease-free water (Applied Biosystems, USA). For nested-PCR reaction $1 \mu \mathrm{l}$ from the primary PCR was added. The size of the amplified DNA fragment was 546 base pairs (bp). Products of amplification were identified in $2 \%$ agarose gel, after electrophoresis in standard conditions and staining with ethidium bromide solution $(2 \mu \mathrm{g} / \mathrm{ml})$. DNA isolated from antigen $A$. phagocytophilum on the substrate slide (Focus Diagnostic, CA, USA) was used as a positive control and nuclease-free water as negative control.

Rickettsia spp. detection was performed as described previously by Wójcik-Fatla et al. [29] using primers RpCS.887p and RpCS.1258n specific for a gene gltA encoding the citrate synthase [45]. DNA isolated from antigen Rickettsia spp. on the substrate slide (Fuller Laboratories, CA, USA) was used as a positive control.

The presence of B. burgdorferi sensu lato (s. 1.) in ticks was evaluated with use of primers FLA1 and FLA2 [46, 47] specific for fla gene. Genus of B. burgdorferi s.l. from positive samples was confirmed by nested PCR, according to method described by Wójcik-Fatla et al. [36]. 
Detection of Babesia spp. has been performed according to methods described previously [31], using the primers described by Persing et al. [48] and by Hilpertshauser et al. [49].

Detection of T. gondii DNA was based on amplification of the B1 fragment gene according to Grigg and Boothroyd [50], with modification described previously by Wójcik-Fatla et al. [38].

Detection of TBEV was carried out using nested RT-PCR (reverse transcription-polymerase chain reaction) with primers specific for the 5'-terminal non-coding region, as described by Schrader and Süss [51] with some modifications [24].

DNA sequencing. Sequencing of positive samples was performed with ABI PRISM 310 Genetic Analyzer using Abi Prism Big Dye Terminator v. 3.1. Cycle Sequencing Kits and Big Dye XTerminator Purification Kit (Applied Biosystems). The results were compared with sequences in the GenBank database using the BLAST server.

Statistical analysis. The results concerning prevalence of individual pathogens in examined ticks were analyzed by $\chi^{2}$ test and Student's t-test, using the STATISTICA v. 6.0 package (Statsoft, Tulsa, OK, USA). The significance of co-infections was assessed with 2 methods: by the Fisher's exact test using GraphPad software [52] and by Odds Ratio calculation using MedCalc ${ }^{\circledast}$ software [53]. The value of $\mathrm{P}<0.05$ was considered as significant and the value of $0.05<\mathrm{P}<0.1$ as weakly significant. The test provided an answer to the questions whether the observed prevalence of co-infections was greater or smaller than expected by chance, and whether this relationship was significant $(\mathrm{P}<0.05)$, weakly significant $(0.05<\mathrm{P}<0.1)$ or not significant $(\mathrm{P}>0.05)$.

\section{RESULTS}

Prevalence of infections with 6 pathogens among Dermacentor reticulatus ticks. The proportion of ticks infected with Rickettsia spp. was large (43.8\%, on the average), much greater compared to other pathogens. As much as $8.5 \%$ of examined ticks were infected with the TBE virus. The infection rates with Babesia spp., Toxoplasma gondii, Borrelia burgdorferi s.l., and Anaplasma phagocytophilum were smaller, amounting to $2.5 \%, 2.1 \%, 1.6 \%$ and $1.1 \%$, respectively (Tab. 1).

Sequencing analysis of PCR positive samples confirmed the $100 \%$ homology with sequences deposited in GenBank - for Anaplasma phagocytophilum [Accession No. CP015376.1], Tick-borne encephalitis virus [FJ572210.1], Toxoplasma gondii [LN714499.1], for Rickettsia spp. the comparison evidenced R. raoultii [KU310590.1], and for B. burgdorferi s.l positive samples - analysis confirmed B. afzelii [KR782215.1]. Among Babesia spp. positive samples, 12 were confirmed as B. microti [AB085191.1] and 4 as B. canis [KM111283.1].

The infection rate with $T$. gondii was significantly greater in males for total examined tick population $(\mathrm{P}=0.0448)$ and for the Włodawa locality $(\mathrm{P}=0.0159)$. Similarly, males were infected significantly more often with Babesia spp. in Parczew $(\mathrm{P}=0.0242)$ and in total tick population, where the difference was only weakly significant $(\mathrm{P}=0.0817)$. By contrast, female ticks in Parczew were infected significantly more often with B. burgdorferi s.l. $(\mathrm{P}=0.0315)$. For TBEV, Anaplasma phagocytophilum, and Rickettsia raoultii, no significant differences were found between infection rates in males and females.

The greatest locality-dependent variability was found for TBE virus, having been significant for females $\left(\chi^{2}=8.609\right.$; $\mathrm{P}=0.0135)$, males $\left(\chi^{2}=8.973 ; \mathrm{P}=0.0113\right)$, and total tick population $\left(\chi^{2}=11.063 ; \mathrm{P}=0.004\right)$. For Toxoplasma gondii, this variability was significant for males $\left(\chi^{2}=12.056\right.$; $\left.\mathrm{P}=0.0024\right)$ and total tick population $\left(\chi^{2}=11.298 ; \mathrm{P}=0.0035\right)$, while for Borrelia burgdorferi s.l. it was significant only for males $\left(\chi^{2}=6.100 ; \mathrm{P}=0.0474\right)$. No significant locality-dependent variability was found for A. phagocytophilum, Rickettsia raoultii, and Babesia spp.

Co-infections with multiple pathogens and their significance. Of the total $634 \mathrm{D}$. reticulatus specimens examined, $310(48.9 \%)$ were not infected with any of the 6 pathogens tested, $270(42.6 \%)$ were infected with a single

Table 1. Prevalence of 6 pathogens in the population of Dermacentor reticulatus ticks collected in eastern Poland

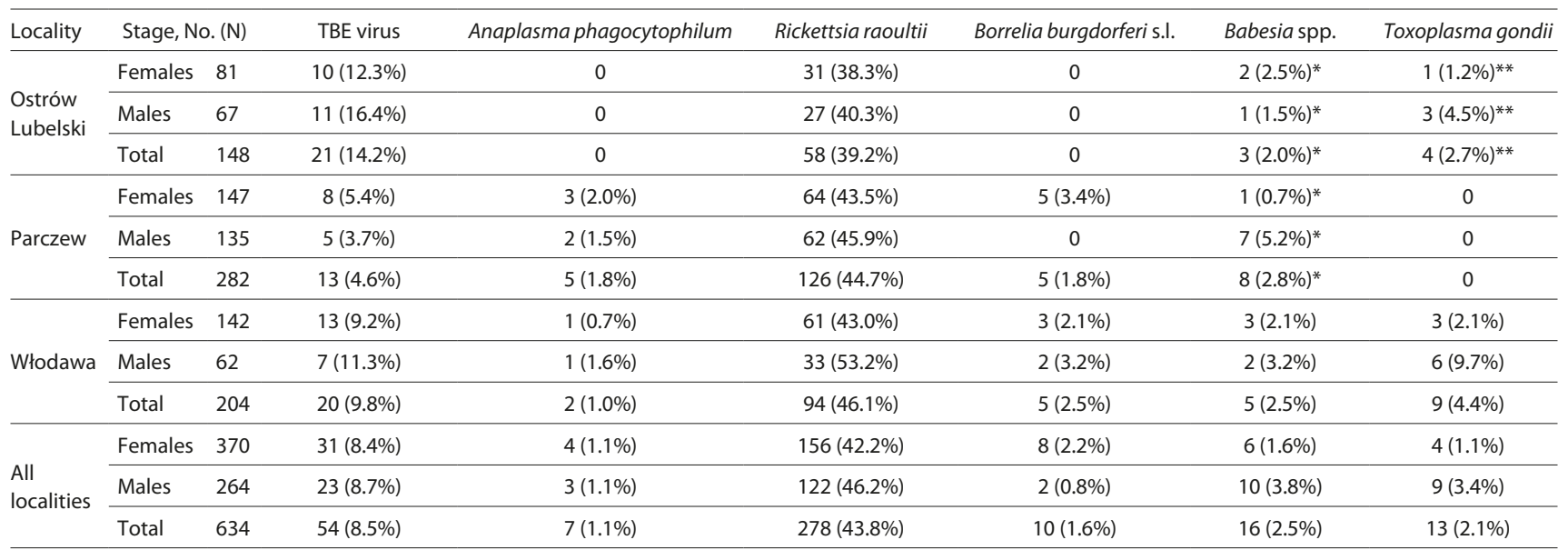

In each space there is shown the number of infected ticks and percent of the total in parentheses.

* results previously published in: Wójcik-Fatla A, Zając V, Sawczyn A, Cisak E, Dutkiewicz J.: Babesia spp. in questing ticks from eastern Poland: prevalence and species diversity. Parasitol Res. 2015 Aug; 114(8):3111-6. doi: 10.1007/s00436-015-4529-5.

** results previously published in: Wójcik-Fatla A, Sroka J, Zając V, Sawczyn A, Cisak E, Dutkiewicz J.: Toxoplasma gondii (Nicolle et Manceaux, 1908) detected in Dermacentor reticulatus (Fabricius) (Ixodidae). Folia Parasitol (Praha). 2015 Sep 18;62. pii: 2015.055. doi: 10.14411/fp.2015.055. 
Table 2. Co-infections in Dermacentor reticulatus: prevalence and significance

\begin{tabular}{|c|c|c|c|c|}
\hline $\begin{array}{l}\text { TBE virus } \\
\text { (TBEV) }\end{array}$ & $\begin{array}{l}\text { Versus A. phagocytophilum } \\
\text { C: } 2(0.32 \%) \\
\text { OR: } 4.423195 \% \text { Cl: } 0.84-23.36 \\
P_{O R}: 0.0799 * P_{\text {Fisher }}: 0.1134\end{array}$ & $\begin{array}{l}\text { Versus Rickettsia raoultii } \\
\text { C: } 27 \text { (4.26\%) } \\
\text { OR: } 1.310895 \% \text { Cl: } 0.75-2.29 \\
P_{O R}: 0.3420 \mathrm{P}_{\text {Fisher }}: 0.3902\end{array}$ & $\begin{array}{l}\text { Versus B. burgdorferi s. I. } \\
\text { C: } 1(0.16 \%) \\
\text { OR: } 1.197195 \% \text { Cl: } 0.15-9.63 \\
P_{O R}: 0.8657 \mathrm{P}_{\text {Fisher }}: 0.5922\end{array}$ & $\begin{array}{l}\text { Versus Babesia spp. } \\
\text { NC }\end{array}$ \\
\hline $\begin{array}{l}\text { Anaplasma } \\
\text { phagocytophilum }\end{array}$ & $\begin{array}{l}\text { Versus Rickettsia raoultii } \\
\text { C: } 4 \text { (0.63\%) } \\
\text { OR: } 1.717895 \% \text { Cl: } 0.38-7.74 \\
P_{O R}: 0.4811 \mathrm{P}_{\text {Fisher }}: 0.7050\end{array}$ & $\begin{array}{l}\text { Versus B. burgdorferi s. I. } \\
\text { NC }\end{array}$ & $\begin{array}{l}\text { Versus Babesia spp. } \\
\text { NC }\end{array}$ & $\begin{array}{l}\text { Versus Toxoplasma gondii } \\
\text { NC }\end{array}$ \\
\hline $\begin{array}{l}\text { Rickettsia } \\
\text { raoultii }\end{array}$ & $\begin{array}{l}\text { Versus B. burgdorferi s. I. } \\
\text { C: } 7 \text { (1.10\%) } \\
\text { OR: } 3.039495 \% \text { Cl: } 0.78-11.86 \\
P_{O R}: 0.1096 \mathrm{P}_{\text {Fisher }}: 0.1141\end{array}$ & $\begin{array}{l}\text { Versus Babesia spp. } \\
\text { C: } 3(0.47 \%) \\
\text { OR: } 0.287895 \% \mathrm{Cl}: 0.08-1.02 \\
\mathrm{P}_{\mathrm{OR}}: 0.0537^{\#} \mathrm{P}_{\text {Fisher }}: 0.0437^{\# \#}\end{array}$ & $\begin{array}{l}\text { Versus Toxoplasma gondii } \\
\text { C: } 6(0.95 \%) \\
\text { OR: } 1.09895 \% \text { Cl: } 0.37-3.31 \\
\mathrm{P}_{\mathrm{OR}}: 0.8656 \mathrm{P}_{\text {Fisher }}: 1.000\end{array}$ & \\
\hline $\begin{array}{l}\text { Borrelia } \\
\text { burgdorferi s. I. }\end{array}$ & $\begin{array}{l}\text { Versus Babesia spp. } \\
\text { NC }\end{array}$ & $\begin{array}{l}\text { Versus Toxoplasma gondii } \\
\text { NC }\end{array}$ & & \\
\hline Babesia spp. & $\begin{array}{l}\text { Versus Toxoplasma gondii } \\
\text { C: } 1 \text { (0.16\%) } \\
\text { OR: } 3.366795 \% \text { Cl: } 0.41-27.59 \\
P_{\text {OR }}: 0.2580 \mathrm{P}_{\text {Fisher }}: 0.2850\end{array}$ & & & \\
\hline Toxoplasma gondii & $\begin{array}{l}\text { Versus TBE virus } \\
C: 3(0.47 \%) \\
\text { OR: } 3.352995 \% \text { Cl: } 0.89-12.57 \\
P_{O R}: 0.0728^{*} P_{\text {Fisher }}: 0.0907^{*}\end{array}$ & & & \\
\hline 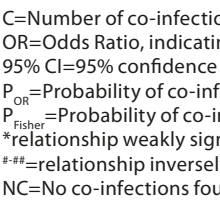 & $\begin{array}{l}\text { ent related to the total tick populati } \\
\text { of infections with pathogen " } \mathrm{A} \text { " in tic } \\
\text { OR; } \\
\text { sed by Odds Ratio; } \\
\text { essed by the Fisher's exact test. } \\
5<\mathrm{P}<0.1) \text {; } \\
\text { (more infections with pathogen " } \mathrm{A} \text { " }\end{array}$ & $\begin{array}{l}\text { examined ( } 634 \text { specimens); } \\
\text { infected also with pathogen " } B \text { " to } \\
\text { ticks not harboring pathogen " } B \text { "): }\end{array}$ & $\begin{array}{l}\text { nfections with pathogen " } A \text { " in tick } \\
<P<0.1 \text {, } " \#<0.05\end{array}$ & harbouring pathogen "B"; \\
\hline
\end{tabular}

pathogen, and $54(8.5 \%)$ showed the presence of dual coinfections, each with 2 pathogens. No simultaneous infections with 3 or more pathogens were found. The occurrence of dual co-infections and the assessment of their significance performed with 2 methods are presented in Table 2.

As seen in Table 2, the most common were dual infections with participation of Rickettsia raoultii (7.41\%), followed by those with participation of the TBE virus (5.21\%). Less common were dual infections with participation of T. gondii, B. burgdorferi s.l., A. phagocytophilum, and Babesia spp. (1.58\%, $1.26 \%, 0.95 \%$, and $0.63 \%$, respectively). Of the total number of 15 possible associations, in 9 cases co-infections occurred, whereas in 6 cases they were not detected (Tab. 2). The most noteworthy were positive coinfections with participation of TBE virus which proved to be weakly significant $(0.05<\mathrm{P}<0.1)$ at associations with T. gondii and A. phagocytophilum (Tab. 2). The Odds Ratios were respectively over 3.3 and 4.4, respectively, which means that the probability of infection with TBE virus (TBEV) was 3-4 times greater at the presence of the above-mentioned pathogens. The values of Odds Ratios exceeded 3.0 also at the co-infections of Rickettsia raoultii with B. burgdorferi s.l., and T. gondii with Babesia spp., but these associations did not attain a significance level. It is interesting that the co-infections of Rickettsia raoultii with Babesia spp. appeared to be negatively correlated with OR below 0.3 , which means that the infections with bacteria of the species $R$. raoultii are less common at the presence of Babesia protozoans. In conclusion, co-infections with various pathogens in $D$. reticulatus ticks seem to be relatively rare and mostly not significant.

\section{DISCUSSION}

So far, there is only scarce information on co-infections with various pathogens in Dermacentor reticulatus, and the presented study, revealing $8.5 \%$ of dual infections in this tick species, is the first attempt at statistical assessment of this problem, based on a greater number of specimens examined. Until recently, the only statistical evaluation of these coinfections had been performed by Tomanović et al. [28] in Serbia, who studied the prevalence of 9 microorganisms in 53 D. reticulatus specimens, and detected only 2 types of dual infections: between Coxiella burnetii and Francisellalike endosymbiont (FLE), and between Babesia canis and FLE. The latter association showed a significantly higher prevalence rate than expected. Reye et al. [27] found coinfections in 3 out 226 D. reticulatus ticks (1.3\%) which were collected in Belarus and tested for the presence of 7 pathogens. This value, which is 6.5 times lower compared to the current study, concerned in all cases co-infections between B. burgdorferi s.l. and Rickettsia spp. Similarly, a coinfection value 2.8 times lower compared to the current study was reported Mierzejewska et al. [30] who examined the Eastern and Western populations of the adult D. reticulatus ticks collected in Poland for the presence of 4 pathogens (Rickettsia spp., Babesia spp., B. burgdorferi s. 1., TBEV), and found $3.0 \%$ of dual infections in the Eastern population (2.7\% of R. raoultii with B. canis, and $0.3 \%$ of $R$. raoultii with $\mathrm{TBEV}$ ), while in the Western population no such infections were found. The smaller value of co-infections reported also Ionita et al. [54], who found that $5.3 \%$ of D. reticulatus ticks collected from dogs in Romania, were simultaneously infected with Rickettsia raoultii and Babesia canis.

Among the pathogens determined in the course of the present work in D. reticulatus, the greatest prevalence showed Rickettsia raoultii causing spotted fever and tick-borne 
encephalitis virus (TBEV). Taking into consideration the detected co-infections, the greatest risk is posed by TBEV, the only pathogen that revealed a weakly significant $(0.05<\mathrm{P}<0.1)$ positive association with Anaplasma phagocytophilum and Toxoplasma gondii. In particular, the co-infection of TBEV and T. gondii could be of clinical importance because both pathogens are neurotropic. Considering the significant locality-dependent variability of TBEV, its distribution in eastern Poland most probably has a focal character. Rickettsia raoultii showed only a negative association with Babesia spp., which means that the probability of the tick infection with Babesia spp. is more than 3 times smaller in the presence of $R$. raoultii.

The frequency of co-infections found in the presented study in D. reticulatus (8.5\%) is essentially lower compared to analogous co-infections reported for Ixodes ricinus complex, although usually in the latter case co-infections involving less than 6 pathogens were analyzed. Thus, Steiner et al. [55] found $45 \%$ dual and triple infections in I. scapularis ticks which were tested in the USA for the presence of B. burgdorferi s.l., A. phagocytophilum, Babesia spp., and the rickettsial endosymbiont. Similarly, Tokarz et al. [56] found $38.1 \%$ dual and triple infections in I. scapularis ticks which were examined in New York State, USA, for the presence of B. burgdorferi s.l., Borrelia miyamotoi, A. phagocytophilum, Babesia microti, and Powassan virus. In three European studies performed in France [57], Luxembourg [58] and Belarus [27], where $I$. ricinus ticks were tested with a greater number of pathogens (6, 7 and 7, respectively), co-infections frequencies $16.3 \%$ (twice as many as in present study), 3.2\% (2.7 times less than in the present study) and 3.4\% (2.5 times less than in the present study) were respectively found.

We did not observe in $D$. reticulatus any dual infections with B. burgdorferi s.l. and A. phagocytophilum, with B. burgdorferi s.l. and Babesia spp., and with $A$. phagocytophilum and Babesia spp. Such co-infections were also not detected by other authors who examined $D$. reticulatus for the presence of a greater number of pathogens in Belarus [27], Serbia [28], Russia [20], and Poland [59], while in most studies on I. ricinus complex, these co-infections are usually reported and analyzed. Thus, Belongia [2] and Swanson et al. [1] report in their review articles the prevalence of dual co-infections between B. burgdorferi s. 1. and A. phagocytophilum or Babesia microti/B. divergens, ranging between 1.0-1.3\% for I. pacificus, between 1.0-28.2\% for I. scapularis, between $0-13.4 \%$ for I. ricinus, and between $0.5-1.2 \%$ for I. persulcatus. Alekseev et al. [60] found that in I. persulcatus ticks collected in Russia, the infection with $B$. microti occurred only in a significant association with $B$. burgdorferi s.l., which resulted in a more severe and longer-lasting disease in humans attacked by the ticks. In Ixodes ricinus ticks collected in various regions of Poland, the prevalence of co-infections between $B$. burgdorferi s.l. and A. phagocytophilum ranged from $0.9-8.3 \%$, between $B$. burgdorferi s.l. and B. microti from $0.1-0.6 \%$, and between $A$. phagocytophilum and B. microti from $1.05-2.0 \%$, while the frequency of triple infections between these 3 pathogens ranged from $0-0.06 \%$ [61]. In the Lublin Region, co-infections between B. burgdorferi s.l. and $A$. phagocytophilum, and between A. phagocytophilum and $B$. microti occurred in $I$. ricinus significantly more often than expected $(\mathrm{P}<0.001)$ [62]. Recently, Prusinski et al. [63] reported the average rates of co-infections in adult $I$. scapularis ticks collected in the USA as $6.3 \%$ for B. burgdorferi and
A. phagocytophilum, $1.5 \%$ for B. burgdorferi and B. microti, and $0.6 \%$ for $A$. phagocytophilum and B. microti. The coinfections occurred more frequently than expected by chance $(\mathrm{P}<0.0001)$.

In the presented study, when co-infections with the participation of Rickettsia raoultii were excluded, the prevalence of remaining co-infections was only $1.1 \%$, and single infections ranged from $1.1 \%-8.4 \%$. These relatively low results compared with infection and co-infection rates within $I$. ricinus could be connected with the shortened $D$. reticulatus life-cycle, where nymphs are active only for one month and there is no opportunity for co-feeding larvae and nymphs [26]. To the best our knowledge, the transovarial and transstadial transmission of the investigated pathogens has not been confirmed within the $D$. reticulatus population, with the exception of transovarial transmission of the TBEV via eggs from an infected adult females to offsprings [64]. Pathogens circulation is possible by transfer between hosts and vectors, but regarding the ability of adult D. reticulatus to survive in nature without hosts for even 3-4 years [26], this tick species seems to be a less competent reservoir and vector than I. ricinus.

Little is known about pathogen-pathogen and pathogen-tick interactions. Concerning the transmission of B. burgdorferi, the OspA protein seems to be the key agent responsible for the growth of spirochetes in ticks. The gene TROSPA coding tick receptor for OspA is strongly expressed in larvae and nymphs, compared to adult ticks [65]. Antunes et al. [66] confirmed that receptor TROSPA was over-expressed in Rhipicephalus tick after Babesia bigemina infection, and may be involved in Babesia-tick interactions. To the best of our knowledge, there is no study confirming the role of TROSPA receptor in $D$. reticulatus ticks, which may explain the lower prevalence of $B$. burgdorferi in D. reticulates, compared to I. ricinus. Studies by Moniuszko et al. [67] concerning interactions between pathogens in ticks confirmed that $B$. burgdorferi s.s. increased short-term replication of Ehrlichia ruminantium and Semliki Forest virus, while these pathogens did not affect replication of Borrelia. On the other hand, a study by Levin and Fish [68] on mice and I. scapularis showed no evidence of interaction between $B$. burgdorferi and A. phagocytophilum, and indicated that transmission of both pathogens was independent, the same as in case of a single bacterium.

According to some authors, there are a large number of factors contributing to the geographical spread of D. reticulatus, such as climate change, increasing wildlife population and more fallow lands [26]. The role of D. reticulatus ticks in pathogen circulation in the natural environment may increase within the next few years, when some co-infections occurring in $D$. reticulatus could become important, both from the medical and veterinary viewpoint.

\section{CONCLUSION}

In conclusion, the co-infections with various pathogens occurred in D. reticulatus less often than in the ticks of the Ixodes ricinus complex, although some of them could be important from the medical and veterinary viewpoint. Among the co-infections present in $D$. reticulatus, the most significant seem to be those with the participation of $\mathrm{TBEV}$, while of no importance are those characteristic for 
Violetta Zając, Angelina Wójcik-Fatla, Anna Sawczyn, Ewa Cisak, Jacek Sroka, Anna Kloc et al. Prevalence of infections and co-infections with 6 pathogens...

the Ixodes ricinus complex: between B. burgdorferi s.l. and A. phagocytophilum, between B. burgdorferi s.l. and Babesia spp., and between A. phagocytophilum and Babesia spp.

\section{Acknowledgments}

This study was supported by the National Science Centre (Grant No. N N404267640).

\section{REFERENCES}

1. Swanson SJ, Neitzel D, Reed KD, Belongia EA. Coinfections acquired from Ixodes ticks. Clin Microbiol Rev. 2006; 19: 708-727.

2. Belongia EA. Epidemiology and impact of coinfections acquired from Ixodes ticks. Vector Borne Zoonotic Dis. 2002; 2: 265-273.

3. Ginsberg HS. Potential effects of mixed infections in ticks on transmission dynamics of pathogens: comparative analysis of published records. Exp Appl Acarol. 2008; 46: 29-41.

4. Nieto NC, Foley JE. Meta-analysis of coinfection and coexposure with Borrelia burgdorferi and Anaplasma phagocytophilum in humans, domestic animals, wildlife, and Ixodes ricinus-complex ticks. Vector Borne Zoonotic Dis. 2009; 9: 93-102.

5. Lommano E, Bertaiola L, Dupasquier C, Gern L. Infections and coinfections of questing Ixodes ricinus ticks by emerging zoonotic pathogens in Western Switzerland. Appl Environ Microbiol. 2012; 78: 4606-4612.

6. Chitimia-Dobler L. Spatial distribution of Dermacentor reticulatus in Romania. Vet Parasitol. 2015; 214: 219-223.

7. Karbowiak G. The occurrence of the Dermacentor reticulatus tick - its expansion to new areas and possible causes. Ann Parasitol. 2014; 60: 37-47.

8. Rubel F, Brugger K, Pfeffer M, Chitimia-Dobler L, Didyk YM, Leverenz S, Dautel H, Kahl O. Geographical distribution of Dermacentor marginatus and Dermacentor reticulatus in Europe. Ticks Tick Borne Dis. 2016; 7: 224-233.

9. Estrada-Peňa A, Jongejan F.Ticks feeding on humans: a review of records on human-biting Ixodoidea with special reference to pathogen transmission. Exp. Appl. Acarol. 1999; 23: 685-715.

10. Bartosik K, Wiśniowski L, Buczek A. Abundance and seasonal activity of adult Dermacentor reticulatus (Acari: Amblyommidae) in eastern Poland in relation to meteorological conditions and the photoperiod. Ann Agric Environ Med. 2011; 18: 340-344.

11. Buczek A, Bartosik K. Ticks (Ixodida: Ixodidae, Amblyommidae) in south-eastern Poland and their medical and epidemiological importance. Zdr Publ. 2011; 121: 392-397.

12. Bartosik K, Wiśniowski L, Buczek A. Questing behavior of Dermacentor reticulatus adults (Acari: Amblyommidae) during diurnal activity periods in eastern Poland. J Med Entomol. 2012; 49: 859-864.

13. Buczek A, Bartosik K, Wiśniowski L, Tomasiewicz K. Changes in population abundance of adult Dermacentor reticulatus (Acari: Amblyommidae) in long-term investigations in eastern Poland. Ann Agric Environ Med. 2013; 20: 269-272.

14. Buczek A, Bartosik K, Zając Z. Changes in the activity of adult stages of Dermacentor reticulatus (Ixodida: Amblyommidae) induced by weather factors in eastern Poland. Parasit Vectors. 2014; 7: 245.

15. Mierzejewska EJ, Alsarraf M, Behnke JM, Bajer A. The effect of changes in agricultural practices on the density of Dermacentor reticulatus ticks. Vet Parasitol. 2015; 211: 259-265.

16. Mierzejewska EJ, Estrada-Peña A, Alsarraf M, Kowalec M, Bajer A. Mapping of Dermacentor reticulatus expansion in Poland in 2012-2014. Ticks Tick Borne Dis. 2016; 7: 94-106.

17. Zając Z, Bartosik K, Buczek A. Factors influencing the distribution and activity of Dermacentor reticulatus (F.) ticks in an anthropopressureunaffected area in central-eastern Poland. Ann Agric Environ Med. 2016; 23: 270-275. doi: 10.5604/12321966.1203889.

18. Földvári G, Široký P, Szekeres S, Majoros G, Sprong H. Dermacentor reticulatus: a vector on the rise. Parasit Vectors. 2016; 9: 314

19. Kahl O, Janetzki C, Gray JS, Stein J, Bauch RJ. Tick infection rates with Borrelia: Ixodes ricinus versus Haemaphysalis concinna and Dermacentor reticulatus in two locations in eastern Germany. Med Vet Entomol. 1992; 6: 363-366.

20. Rar VA, Fomenko NV, Dobrotvorsky AK, Livanova NN, Rudakova SA, Fedorov EG, Astanin VB, Morozova OV. Tickborne pathogen detection, Western Siberia, Russia. Emerg Infect Dis. 2005; 11: 1708-1715.
21. Dautel H, Dippel C, Oehme R, Hartelt K, Schetter E. Evidence for increased geographical distribution of Dermacentor reticulatus in Germany and detection of Rickettsia sp. RpA4. Int J Microbiol. 2006; 296 (Suppl. 40): 149-156.

22. Stańczak J. Detection of spotted fever group (SFG) rickettsiae in Dermacentor reticulatus (Acari: Ixodidae) in Poland. Int J Med Microbiol. 2006; 296: 144-148.

23. Biaduń W, Rzymowska J, Stępień-Rukasz H, Niemczyk M, Chybowski J. Occurrence of Borrelia burgdorferi sensu lato in Ixodes ricinus and Dermacentor reticulatus ticks collected from roe deer and deer shot in the south-east of Poland. Bull Vet Inst Pulawy. 2007; 51: 213-217.

24. Wójcik-Fatla A, Cisak E, Zajac V, Zwoliński J, Dutkiewicz J. Prevalence of tick-borne encephalitis virus in Ixodes ricinus and Dermacentor reticulatus ticks collected from the Lublin region (eastern Poland). Ticks Tick Borne Dis. 2011; 2: 16-19.

25. Wójcik-Fatla A, Bartosik K, Buczek A, Dutkiewicz J. Babesia microti in adult Dermacentor reticulatus ticks from eastern Poland. Vector Borne Zoonotic Dis. 2012; 12: 841-843.

26. Földvári G, Rigó K, Lakos A. Transmission of Rickettsia slovaca and Rickettsia raoultii by male Dermacentor marginatus and Dermacentor reticulatus ticks to humans. Diagn Microbiol Infect Dis. 2013; 76: 387-389.

27. Reye AL, Stegniy V, Mishaeva NP, Velhin S, Hübschen JM. Ignatyev G, Muller CP. Prevalence of tick-borne pathogens in Ixodes ricinus and Dermacentor reticulatus ticks from different geographical locations in Belarus. PLOS ONE 2013; 8, e54476.

28. Tomanović S, Chochlakis D, Radulović Ž, Milutinović M, Ćakić S, Mihaljica D, Tselentis Y, Psaroulaki A. Analysis of pathogen cooccurrence in host-seeking adult hard ticks from Serbia. Exp Appl Acarol. 2013; 59: 367-376.

29. Wójcik-Fatla A, Cisak E, Zając V, Sroka J, Sawczyn A, Dutkiewicz J. Study on tick-borne rickettsiae in eastern Poland. I. Prevalence in Dermacentor reticulatus (Acari: Amblyommidae). Ann Agr Env Med. 2013; 20: 276-279.

30. Mierzejewska EJ, Pawełczyk A, Radkowski M, Welc-Falęciak R, Bajer A. Pathogens vectored by the tick, Dermacentor reticulatus, in endemic regions and zones of expansion in Poland. Parasit Vectors. 2015; 8: 490.

31. Wójcik-Fatla A, Zając V, Sawczyn A, Cisak E, Dutkiewicz J. Babesia spp. in questing ticks from eastern Poland: prevalence and species diversity. Parasitol. Res. 2015; 114: 3111-3116.

32. Wójcik-Fatla A, Zając V, Sawczyn A, Cisak E, Sroka J, Dutkiewicz J. Occurrence of Francisella spp. in Dermacentor reticulatus and Ixodes ricinus ticks collected in eastern Poland. Ticks Tick Borne Dis. 2015; 6: 253-257.

33. Heile C, Heydorn AO, Schein E. Dermacentor reticulatus (Fabricius, 1794) - distribution, biology and vector for Babesia canis in Germany. Berl Munch Tierarztl Wochenschr. 2006; 119: 330-334 (in German).

34. Beelitz P, Schumacher S, Marholdt F, Pfister K, Silaghi C. The prevalence of Babesia canis canis in marsh ticks (Dermacentor reticulatus) in the Saarland. Berl. Munch. Tierarztl. Wochenschr. 2012; 125: 168-171 (in German)

35. Biernat B, Karbowiak G, Werszko J, Stańczak J. Prevalence of tickborne encephalitis virus (TBEV) RNA in Dermacentor reticulatus ticks from natural and urban environment, Poland. Exp Appl Acarol. 2014; 64: 543-551.

36. Wójcik-Fatla A, Zając V, Sawczyn A, Sroka J, Cisak E, Dutkiewicz J. Infections and mixed infections with the selected species of Borrelia burgdorferi sensu lato complex in Ixodes ricinus ticks collected in eastern Poland: a significant increase in the course of 5 years. Exp Appl Acarol. 2016; 68: 197-2012.

37. Dubey JP. Toxoplasmosis of Animals and Humans. $2^{\text {nd }}$ Ed. CRC Press, Boca Raton, FL 2010

38. Wójcik-Fatla A, Sroka J, Zając V, Sawczyn A, Cisak E, Dutkiewicz J. Toxoplasma gondii (Nicolle et Manceaux, 1908) detected in Dermacentor reticulatus (Fabricius) (Ixodidae). Folia Parasit. 2015; 62: 2015.055.

39. Sroka J, Chmielewska-Badora., Dutkiewicz J. Ixodes ricinus as a potential vector of Toxoplasma gondii. Ann Agric Environ Med. 2003; 10: $121-123$

40. Sroka J, Wójcik-Fatla A, Zwoliński J, Zając V, Sawczuk M, Dutkiewicz J. Preliminary study on the occurrence of Toxoplasma gondii in Ixodes ricinus ticks from north-western Poland with the use of PCR. Ann Agric Environ Med. 2008; 15: 333-338.

41. Asman M, Solarz K, Cuber P, Gąsior T, Szilman P, Szilman E, Tondaś E, Matzullok A, Kusion N, Florek K. Detection of protozoans Babesia microti and Toxoplasma gondii and their co-existence in ticks (Acari: Ixodida) collected in Tarnogórski district (Upper Silesia, Poland). Ann Agric Environ Med. 2015; 22: 80-83. 
42. Zhou Y, Zhang H, Cao J, Gong H, Zhou J. Epidemiology of toxoplasmosis: role of the tick Haemaphysalis longicornis. Infect Dis Poverty. 2016; 5: 14.

43. Rijpkema S, Golubic D, Moelkenboer M, Verbeek-De Kruif N, Schellekens J. Identification of four genomic groups of Borrelia burgdorferi sensu lato in Ixodes ricinus ticks collected in a Lyme borreliosis endemic region of northern Croatia. Exp Appl Acarol. 1996; 20: 23-30.

44. Massung RF, Slater K, Owens JH, Nicholson WL, Mather TN, Solberg VB, Olson JG. Nested PCR assay for detection of granulocytic ehrlichiae. J Clin Microbiol. 1998; 36: 1090-1095.

45. Regnery RL, Spruill CL, Plikyatis BD. Genotypic identification of rickettsiae and estimation of interspecies sequence divergence for portions of two rickettsial genes. J Bacteriol. 1991; 173: 1576-1589.

46. Stańczak J, Kubica-Biernat B, Acewicz M, Kruminis-Łozowska W, Kur J. Detection of three genospecies of Borrelia burgdorferi sensu lato in Ixodes ricinus ticks collected in different regions of Poland. Int J Med Microbiol. 2000; 290: 559-566.

47. Wodecka B, Sawczuk M. Occurrence of pathogenic genospecies of Borrelia burgdorferi sensu lato in Ixodes ricinus ticks collected from north-western Poland. Wiad. Parazytol. 2004; 50: 545-553.

48. Persing DH, Mathiesen D, Marshall WF, Telford SR, Apielman A, Thomford JW, Conrad PA. Detection of Babesia microti by polymerase chain reaction. J Clin Microbiol. 1992; 30: 2097-2103.

49. Hilpertshauser H, Deplazes P, Schnyder M, Gern L, Mathis A. Babesia spp. identified by PCR in ticks collected from domestic and wild ruminants in southern Switzerland. Appl Environ Microbiol. 2006; 72: 6503-6507.

50. Grigg ME, Boothroyd JC. Rapid identification of virulent type I strains of the protozoan pathogen Toxoplasma gondii by PCR restriction fragment length polymorphism analysis at the $\mathrm{B} 1$ gene. J. Clin. Microbiol. 2001; 39: 398-400.

51. Schrader C, Süss J. A nested RT-PCR for the detection of tick-borne encephalitis virus (TBEV) in ticks in natural foci. Zbl. Bakteriol. 1999; 289: 319-328.

52. GraphPad software. http://graphpad.com/quickcalcs/contingencyl. cfm. Graphpad 2015.

53. MedCalc software. http://www.medcalc.org/calc/odds_ratio.php. MedCalc 2015

54. Ionita M, Silaghi C, Mitrea IL, Edouard S, Parola P, Pfister K. Molecular detection of Rickettsia conorii and other zoonotic spotted fever group rickettsiae in ticks, Romania. Ticks Tick Borne Dis. 2016; 7: 150-153.

55. Steiner FE, Pinger RR, Vann CN, Grindle N, Civitello D, Clay K, Fuqua C. Infection and co-infection rates of Anaplasma phagocytophilum variants, Babesia spp., Borrelia burgdorferi, and the rickettsial endosymbiont in Ixodes scapularis (Acari: Ixodidae) from sites in Indiana, Maine, Pennsylvania, and Wisconsin. J Med Entomol. 2008; 45: 289-297.
56. Tokarz R, Jain K, Bennett A, Briese T, Lipkin WA. Assessment of polymicrobial infections in ticks in New York state. Vector Borne Zoonotic Dis. 2010; 10: 217-221.

57. Reis C, Cote M, Paul RE, Bonnet S. Questing ticks in suburban forest are infected by at least six tick-borne pathogens. Vector Borne Zoonotic Dis.2011; 11: 907-916.

58. Reye AL, Hübschen JM, Sausy A, Muller CP. Prevalence and seasonality of tick-borne pathogens in questing Ixodes ricinus ticks from Luxembourg. Appl Environ Microbiol. 2010; 76: 2923-2931.

59. Dzięgiel B, Kubrak T, Adaszek Ł, Dębiak P, Wyłupek D, Bogucka-Kocka A, Lechowsk, J, Winiarczyk S. Prevalence of Babesia canis, Borrelia burgdorferi sensu lato, and Anaplasma phagocytophilum in hard ticks collected from meadows of Lubelskie Voivodship (eastern Poland). Bull Vet Inst Pulawy. 2014; 58: 29-33.

60. Alekseev AN, Semenov AV, Dubinina HV. Evidence of Babesia microti infection in multi-infected Ixodes persulcatus ticks in Russia. Exp Appl Acarol. 2003; 29: 345-353.

61. Siński E. Effect of coinfections in Ixodidae ticks on transmission of blood microparasites. Wiad Parazytol. 2009; 55: 341-347 (in Polish).

62. Wójcik-Fatla A, Szymańska J, Wdowiak L, Buczek A, Dutkiewicz J. Coincidence of three pathogens (Borrelia burgdorferi sensu lato, Anaplasma phagocytophilum and Babesia microti) in Ixodes ricinus ticks in the Lublin macroregion. Ann Agric Environ Med. 2009; 16: 151-158.

63. Prusinski MA, Kokas JE, Hukey KT, Kogut SJ, Lee J, Backenson PB. Prevalence of Borrelia burgdorferi (Spirochaetales: Spirochaetaceae), Anaplasma phagocytophilum (Rickettsiales: Anaplasmataceae), and Babesia microti (Piroplasmida: Babesiidae) in Ixodes scapularis (Acari: Ixodidae) collected from recreational lands in the Hudson Valley Region, New York. State J Med Entomol. 2014; 51: 226-236.

64. Danielová V, Holubová J, Pejcoch M., Daniel M. Potential significance of transovarial transmission in the circulation of tick-borne encephalitis virus. Folia Parasitol. (Praha) 2002; 49: 323-325.

65. Pal U, Li X, Wang T, Montgomery RR, Ramamoorthi N, Desilva AM, Bao F, Yang X, Pypaert M, Pradhan D, Kantor FS, Telford S, Anderson JF, Fikrig E. TROSPA, an Ixodes scapularis receptor for Borrelia burgdorferi. Cell. 2004; 119: 457-468.

66. Antunes S., Galindo R., Almazan C, Rudenko N, Golovchenko M, Grubhoffer L, Shkap V, do Rosário V, de la Fuente J, Domingos A. Functional genomics studies of Rhipicephalus (Boophilus) annulatus ticks in response to infection with the cattle protozoan parasite, Babesia bigemina. Int J Parasitol. 2012; 42: 187-195.

67. Moniuszko A, Rückert C, Alberdi MP, Barry G, Stevenson B, Fazakerley $\mathrm{JK}$, Kohl A, Bell-Sakyi L. Coinfection of tick cell lines has variable effects on replication of intracellular bacterial and viral pathogens. Ticks Tick Borne Dis. 2014; 5: 415-422.

68. Levin ML, Fish D. Acquisition of coinfection and simultaneous transmission of Borrelia burgdorferi and Ehrlichia phagocytophila by Ixodes scapularis ticks. Infect. Immun. 2000; 68: 2183-2186. 